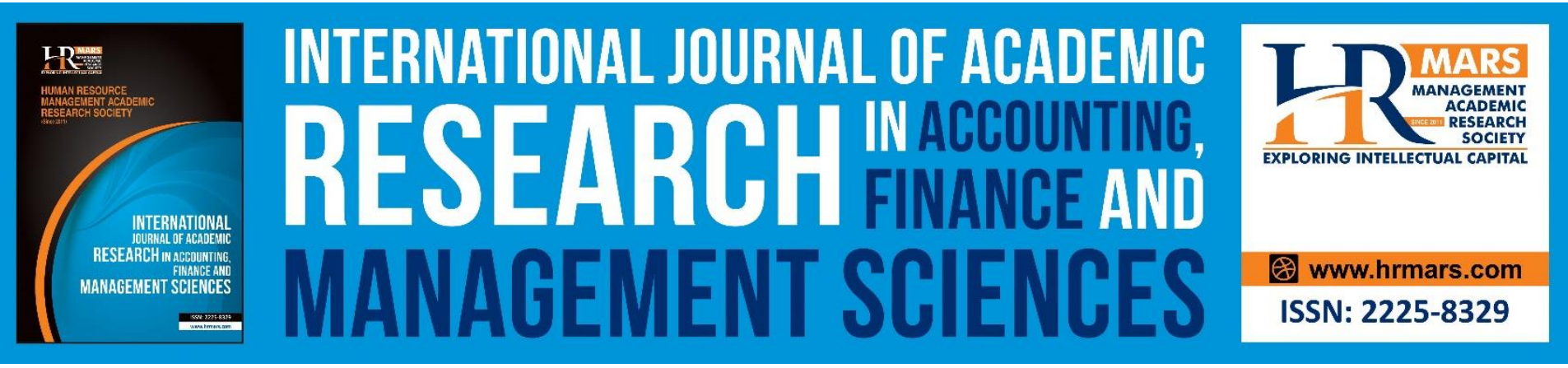

\title{
Knowledge Management and Contemporary Management Accounting Practices of Malaysian Cooperatives Sector: An Empirical Evidence
}

Sharul Effendy Janudin, Hazianti Abdul Halim, Nurul Fadly Habidin

To Link this Article: http://dx.doi.org/10.6007/IJARAFMS/v10-i3/7872

DOI:10.6007/IJARAFMS /v10-i3/7872

Received: 21 June 2020, Revised: 29 July 2020, Accepted: 29 August 2020

Published Online: 28 September 2020

In-Text Citation: (Janudin, Abdul Halim, \& Habidin, 2020)

To Cite this Article: Janudin, S. E., Abdul Halim, H., \& Habidin, N. F. (2020). Knowledge Management and Contemporary Management Accounting Practices of Malaysian Cooperatives Sector: An Empirical Evidence. International Journal of Academic Research in Accounting, Finance and Management Sciences. 10(3), 292308.

Copyright: (c) 2020 The Author(s)

Published by Human Resource Management Academic Research Society (www.hrmars.com)

This article is published under the Creative Commons Attribution (CC BY 4.0) license. Anyone may reproduce, distribute, translate and create derivative works of this article (for both commercial and non-commercial purposes), subject to full attribution to the original publication and authors. The full terms of this license may be seen at: http://creativecommons.org/licences/by/4.0/legalcode

Vol. 10, No. 3, 2020, Pg. 292 - 308

http://hrmars.com/index.php/pages/detail/IJARAFMS

JOURNAL HOMEPAGE

Full Terms \& Conditions of access and use can be found at http://hrmars.com/index.php/pages/detail/publication-ethics 


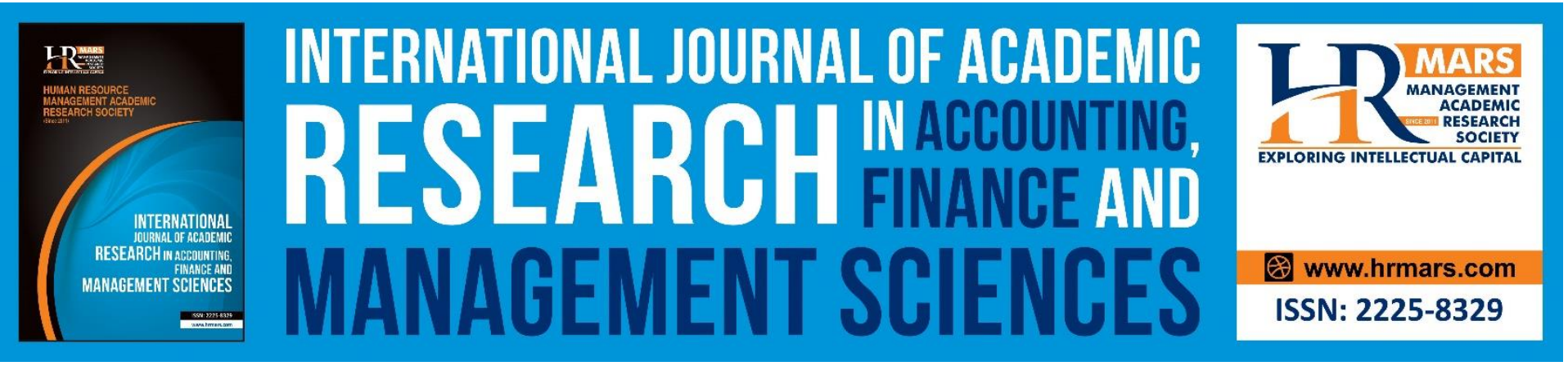

\title{
Knowledge Management and Contemporary Management Accounting Practices of Malaysian Cooperatives Sector: An Empirical Evidence
}

\author{
Sharul Effendy Janudin ${ }^{1}$, Hazianti Abdul Halim ${ }^{1}$, Nurul Fadly \\ Habidin $^{2}$
}

${ }^{1}$ Department of Accounting and Finance, Faculty of Management and Economics, ${ }^{2}$ Department of Business Management and Entrepreneurship, Faculty of Management and Economics, Universiti

Pendidikan Sultan Idris, 35900 Tanjong Malim, Perak

Email: sharul@fpe.upsi.edu.my

\begin{abstract}
Cooperatives in Malaysia are currently operating in a constantly volatile, uncertain, complex and ambiguity situation. The alignment between managers' plan and organization goals can be achieved through the application of knowledge management and contemporary management accounting practices (MAP). Therefore, the purpose of this paper is to examine the association between knowledge management and contemporary management accounting practices (MAP) in the Malaysian' co-operative sector. Data were collected through distribution of mail survey to management team from the 100 leading co-operatives in Malaysia. Descriptive on the knowledge management and adoption level of contemporary management accounting practices has been analyzed. The findings indicate the knowledge management in organizational structure level is high and contemporary MAP is also high. The relationship between knowledge management and contemporary MAP among Malaysian Co-operatives is also significant but at moderate level. The findings suggest that knowledge management is an immerse diversity of knowledge and it will not succeed in an organization unless it is supported by top management. Knowledge management plays an important roles through making explicit the link between effective knowledge management and utilization of contemporary management accounting practices.
\end{abstract}

Keywords: Knowledge Management, Management Accounting Practices, Co-Operatives

\section{Introduction}

At the end of year 2019, 14625 co-operatives were registered under Malaysia Co-operative Societies Commission. National Co-operatives Policy 2011-2020 was launched with the purpose of accelerating the performance of the co-operatives. There are five strategic thrust: stimulate participation of co-operatives in high value economic sector, strengthen the capacity and capability 
of co-operatives, create and develop the capability of human capital in co-operatives, improve public confidence in the co-operative movement; and strengthen co-operatives through effective supervision and enforcement (Malaysia Co-operative Societies Commission, 2011).

In order to be competitive, cooperatives are demanded to be more creative and innovative. For example, cooperatives may design an innovative organizational structure and applying management accounting tools in managing organization. As the sustainability and progress of most organizations including performance, knowledge management through organizational structure boost information exchange and discussion through various channel.

Organizational structure is a system used to establish a hierarchy within an organization. Reporting process, growth of job description and room for organizational expansion can be formalized through it. It is also defines how activities such as planning, organizing, directing, controlling and staffing are directed toward the accomplishment of organizational goals. Knowledge management is the process of defining and sharing the knowledge and experience amongst organizational members. It involves knowledge creation and application through organizational structure. This make knowledge becoming a valuable asset for most organization. A good knowledge management in organizational structure will stimulate better communication, develop clear reporting relationship, efficient task completion and fits organization's needs. It will also impact management accounting practices in the organization.

Contemporary management accounting practices can be defined as a process of providing financial information and resources to the managers in decision making by utilizing latest tools in management accounting. Management accounting practices are routines and often associated with stability and change. In co-operatives, the management accounting practices is often undertaken by the manager. It is important for the individuals in the management roles to plan and execute strategic decision making.

To succeed and thrive, management team of cooperatives must adapt, exploit and fit with the environment and economic situation. In order to gain insight, the objectives of this study are as follows:

- To examine the level of knowledge management applied in cooperative?

- To examine level of contemporary management accounting practices applied in cooperative?

- To examine the relationship between knowledge management and contemporary management accounting practices in cooperative?

\section{Literature Review}

\section{Cooperatives Movement in Malaysia}

Cooperative movement in Malaysia has begun in 1922 with the first cooperative law, the Cooperative Societies Enactment 1922 was approved by the Federated Malay States Meeting Council. Syarikat Bekerjasama-sama Jimat Cermat dan Pinjaman Wang Pekerja-pekerja, Jabatan Pos and Telekom Berhad was the first registered cooperative in Malaysia. To strengthen the monitoring system, The Department of Co-operative Development was setup in 1990 and placed under the Ministry of Land and Co-operative Development.2008 has become the memorable year with the incorporated of Malaysia Co-operatives Societies Commission of Malaysia (SKM) with the main objectives to stimulate the strong and stable development of cooperatives according to the values 
and principles of co-operatives. At the end of year 2019, there are 14,000 cooperatives registered with 6 million members. The Malaysian's top 100 cooperatives have combined assets totaling RM123.4 billion as of year 2019 and Bank Kerjasama Rakyat Malaysia Bhd retains the number one spot in 2019 for the fourth consecutive year. Co-operatives sector in Malaysia has been identified as the third engine of economic growth and the sustainability model must uphold the balance strategies on economic, social, environment and governance (Aris et al., 2018).

\section{Knowledge Management in Organizational Structure}

Knowledge management in organizational structure is a dynamic factor because the configuration of it facilitates the capacity of the organizational to innovate, learn and improve. It also plays an important role in helping management to achieve its strategic objectives. For example, clear organizational structure will help smooth impact on learning process (Maria Martinez-Leon \& Martinez-Garcia, 2011). In Sweden, the flexibility of designing organizational structure can be seen through four patterns: emphasizing service orientation, service-focused organizational structure, emphasizing customer orientation, and customer-focused organizational structure (Gebauer \& Kowalkowski, 2012). Transformation from vertical, hierarchical and functional structures to horizontal and team oriented are a must to adapt the flexibility in decision making.

Many studies have been conducted to understand the impact of knowledge management in organizational structure towards company. Knowledge management practices can be strategized thorough proper setting of organizational structure. An innovative organizational structure will stimulate knowledge sharing (Yao et al., 2020). In Republic of Serbia, organic structure that support knowledge have positive effect on knowledge creation (Stojanovic-Aleksic et al., 2019) and directly influence management to apply the contemporary techniques in management process. Furthermore, the organizational structure within automotive industry in Brazil is the main contextual factor related to knowledge management and dynamic capability(Gonzalez \& Melo, 2017). Therefore, the organizational structure to promote knowledge management should emphasize the adaptation of contemporary techniques in achieving strategic goals of organization. While the construction industry in Sri Lanka which still in the fancy stage of knowledge management has shown that organizational structure is poorly correlated with management performance (Gunasekera \& Chong, 2018).

\section{Contemporary Management Accounting Practices}

Accounting information plays an important role in business organization with management accounting practices being one of the pillar. The readiness of management accounting to coup with the advancement of economic environment offer organizational to survive in competition. According to Janudin (2019), contemporary management accounting should include costing system, budgeting system, strategic analysis, information for decision making and performance measurement system.

\section{Costing System}

A framework used by the organization to calculate costs of their products is called costing system. It will help the organization to do analysis on profit and cost control activity. The advancement of technology has made traditional costing system being replaced by more precise tools. For example, activity-based costing is more accurate compare to determination of overhead cost base on direct labour cost. The process is quite technical if production is based on technology 
intensive. Managers are expected to analyze the nature of expected benefits and costing system prior to implement it.

Activity based costing $(A B C)$ is contemporary costing system because it provides accurate cost calculation. In time, the time-driven activity-based costing (TDABC) is the latest approach for activitybased costing because it involve observation to measure efficiency in productivity (Kont, 2020). In Thailand, extensive use of $A B C$ for cost analysis, cost strategy and cost evaluation directly improves operational performance; it also indirectly improves financial performance (Vetchagool et al., 2020). $A B C$ also is intensively used by the company who focus on expanding their market to global (Sharma \& Sharma, 2020). For example, ABC application at a force's communication centre has reduced staffing cost at $9.4 \%$ (Greasley \& Smith, 2017).

In 2007, standard costing was still being used in the Japanese manufacturing environment to manage product costing despite the technological changes (De Zoysa \& Herath, 2007). Standard costing also part of costing system and the increased enabling used of standard variable costing increases performance in lean production (Kristensen, 2020). The introduction and operation of standard costing at J\&P Coats Ltd from 1925 to 1961 shows that institutional factors affected the implementation of standard costing through factors and changing organizational structures (McKinstry et al., 2019).

\section{Budgeting System}

Budget is one of the contemporary management accounting practices in many organization because of its ability to coordinate and communicate strategic goals, increase organizational members's commitment and improve organizational performance. Budgets are applicable to many organizations such as university (Kuchta et al., 2019), hotel (Alrawadieh et al., 2020).Harun, Carter, Mollik, and An, (2020) reinforce the notion that accounting as a business language and budgeting systems should consider institutional capacities. At the individual level, an interactive use of budgets can affect individual creativity through role clarity (Sitepu et al., 2020).

Throughout the policy reforms in public libraries, budgeting has been proven as a useful tool for predicting the future, resource control, improving departmental performance and boost employee motivation (Rafi et al., 2020). In applying capital budgeting technique, Canadian and Mexican entrepreneurs in small business in the food sector highlighted bounded rationality and prominent role of context is applied differently towards investment decisions (Morales Burgos et al., 2020). In Vietnam, budgetary participation and vertical information sharing has positive effects on work performance (Nguyen et al., 2019). The alignment between top management and operational worker is important to stimulate organizational budget flexibility in continuous improvement projects (Oyadomari et al., 2018). At the university level, complexities of implementation and a lack of continuity of key personnel made it difficult to implement a new budgeting system (Willison \& Buisman-Pijlman, 2016).

\section{Strategic Analysis}

SWOT analysis is main tools applicable in strategic analysis. By doing SWOT analysis, the strength and weaknesses are identified by internal factors while the opportunities and threats are identified by external factors regardless the size of organization. Duarte Alonso and Bressan (2016) conducted SWOT analysis amongst Italian wine firm and they identified product quality, 
managerial/staff capabilities, knowledge, reputation, service quality and the region are the most important resources to sustain competitive. In Turkey, SWOT analysis help electrical manufacturing small and medium sized enterprises (SMEs) to perform efficiently (Bulak et al., 2016). SWOT analysis works effectively in outlining Polytechnique Institute of Braganca, Portugal performance strategies to boost positive reputation (Maduro et al., 2018). Ajmera (2017) integrates SWOT analysis with a multicriteria decision making called TOPSIS in Indian medical tourism to matches SWOT matrix and 35 strategic indicators. The combination was used to select the best strategies to achieve long term objectives. Companies involve in dairy supply chain in Indonesia also use SWOT analysis in formulating the strategic planning of their business to improve strategic performance (Susanty et al., 2018).

Life cycle analysis also one of the tools to perform strategic analysis. The creativity of accountants has incorporated costing into the life cycle analysis. For example, life cycle environmental cost analysis (LCECA) is introduced to identifies the feasible alternatives for costeffective and eco-friendly parts/products (Senthil Kumaran et al., 2001). While life cycle cost analysis (LCCA) for institutional (higher education) buildings also was created to improve facilities management (Shankar Kshirsagar et al., 2010). A case study of Lincoln on the Lake proven the life cycle analysis in costing has provided a simple, uniform and predetermined sustainable designs. (Sacks et al., 2012). Life cycle costs have a significant impact on the financial health because it make informed decision about facility designs and specification (Harris \& Fitzgerald, 2017).

\section{Information for Decision Making}

Cost volume profit analysis (CVP) is a management accounting tool which emphasize employees to make convincing decisions as well to determine volume of production. In India, linear cost volume profit analysis model is more appropriate than the quadratic CVP model for sugar manufacturing companies (Dash, 2020). The application of CVP in analyzing profit planning tour packages at PT Tour East Indonesia, Denpasar has strongly supported CVP can help management to achieve their targeted profit (Dewi et al., 2018). CVP also is used to escalate production capacity and utilize technology to reduce cost of production which directly hiking the profitability from the investors' perspective (Kavitha, 2018).

Cash flow analysis is also important for decision making process in management accounting. In India, the cash levels are significantly higher during crisis period and research has shown that cashflow volatility, firm size, leverage and non-cash working capital requirements help to determine the cash levels (Ranajee \& Pathak, 2019). In the real estate investment decision making framework, standard deviation, discounted cash flow and net present value were most fully utilized (Ekemode \& Olaleye, 2019). In French, family control is positively associated with the cash-flow sensitivity of cash (Guizani et al., 2018). Despite of practicality of cash flow, Dogru and Sirakaya-Turk (2018) found that the effects of cash flows on investment and cash holdings were greater in well-governed hotel firms than in poorly governed hotel firms. Therefore managers should consider their firms cash flow when determining the appropriate investment to be made in working capital (Afrifa, 2016).

Profitability analysis is beneficial through supporting the allocation of complexity costs, understanding of the cost structure of product assortment and providing a basis for generating method to reduce the complexity of products (Hvam et al., 2020). To materialize success product profitability through new product development, international knowledge exploration is essential 
required (Xiao \& Oh, 2019). Organization needs to capture the characteristics of new product such as product value proposition because it will drive the success of product profitability analysis (Cooper, 2019). Hannila, Koskinen, Harkonen, and Haapasalo (2019) proposed data driven and fact based product portfolio management to perform analysis of product profitability.

\section{Performance Measurement System}

Understanding on PMS amongst managers will provide them with relevant information needed to be more effective and efficient in measuring activities and performances. According to Keong Choong (2013) a holistic view of PMS should be balanced between financial and non-financial perspectives, to motivate learning and growth, and improve management and performance. Literature on PMS explains two main functions of performance measures: 1) the decision facilitating roles and 2) the decision influencing role (van VeenDirks, 2010). Cheng and Humphreys (2016) highlights a key strategic control to enable managers to respond to strategic uncertainty is a strategic PMS.

Generally, senior management employs performance measurement system (PMS) as means to translate strategy in to performance measures. Due to the rapid development in technology, increasing use to operationalize PMS in to digital platform via phone and tablets have the potential to exacerbate strategy surrogation effects (Reinking et al., 2020). Guenther and Heinicke (2019) suggest that an increased emphasis on diagnostic use may reduce benefits for the firm when the PMS is more sophisticated. Many measures can be mixed up but Bedford, Bisbe, and Sweeney (2019) reveal that these choices are interdependent. Enhancement must be made in PMS design by showing the relationship between managers' hope for the future, patterns of memory and incompleteness in design (Giovannoni \& Quarchioni, 2019). Managers should be aware of PMS' weaknesses: poor definitions of terms, too many terms are used, terms are used interchangeably and no clear definition of measurement (Choong, 2018).

\section{Knowledge Management and Contemporary Management Accounting Practices}

Knowledge management simply be defined as doing what is needed to get the most out of knowledge resources. It is viewed as an increasingly important discipline that promotes the creation, sharing and leveraging of the organization's knowledge. Having a knowledge management system into an accounting functions will ensure that accounting tools work efficiently in management process. As the output of applying knowledge management, the utilization of management accounting practices enables are at the organization level rather than individual.

At the organizational level, management must work actively to in planning and decision making process. These activities require knowledge, not just on the financial information but of the total information resource available to the organization. Specifically, accountant's involvement in knowledge management is in the area of contemporary management accounting practices. Therefore, six hypothesis have been developed to answer research questions as depicted in figure 1.

H1 There is a significant relationship between knowledge management and costing system in the Malaysian Co-operatives Sector

$\mathrm{H} 2$ There is a significant relationship between knowledge management and budgeting system in the Malaysian Co-operatives Sector 
INTERNATIONAL JOURNAL OF ACADEMIC RESEARCH IN ACCOUNTING, FINANCE AND MANAGEMENT SCIENCES

Vol. 10 , No. 3, 2020, E-ISSN: 2225-8329 @ 2020 HRMARS

H3 There is a significant relationship between knowledge management and strategic analysis in the Malaysian Co-operatives Sector

H4 There is a significant relationship between knowledge management and information for decision making in the Malaysian Co-operatives Sector

H5 There is a significant relationship between knowledge management and performance measurement system in the Malaysian Co-operatives Sector

H6 There is a significant relationship between knowledge management and contemporary management accounting practice in the Malaysian Co-operatives Sector

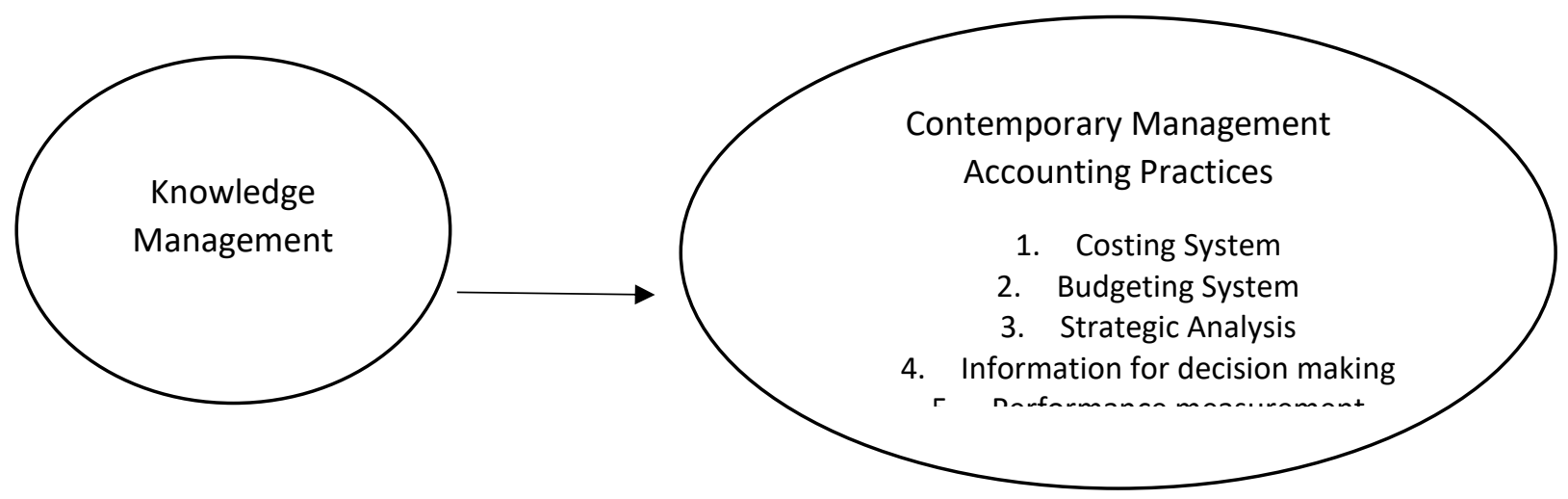

Figure 1: Conceptual Framework

\section{Methodology}

\section{Research Design and Survey Instrument}

This study employed a causal and descriptive research design to determine the cause-and effect relationship among knowledge management and contemporary management accounting practices. The contemporary management accounting practices comprise of costing system, budgeting system, strategic analysis, information for decision making and performance measurement system.

Data gathered through a survey conducted in Malaysia were used to test the hypothesis. A survey is organized covering 100 best co-operatives as listed in directory prepared by Malaysia Cooperatives Societies Commission for 2018. Pilot test is run with an accountants and managers to filter the aim and focal of the survey. Accountants who have vast experience deal with MAP were interviewed to make sure the questionnaires items are easy to understand.

Table 1. No of Best 100 Cooperatives in Malaysia

\begin{tabular}{cc|cc}
\hline STATES & NO OF COOPERATIVES & STATES & NO OF COOPERATIVES \\
\hline Wilayah Persekutuan & 25 & Terengganu & 6 \\
Pahang & 18 & Kedah & 4 \\
Johor & 14 & Sabah & 4 \\
Perak & 9 & Sarawak & 3 \\
Kelantan & 6 & Selangor & 1 \\
Pulau Pinang & 6 & Perlis & \\
\hline
\end{tabular}


Respondents were asked to specify whether co-operative has used each management accounting practice. Respondents are also asked to level of their organization knowledge management. Sampling frame are managers from Malaysian Best 100 Cooperatives and selection base on random sampling method. Each selected co-operatives received three sets of questionnaires and phone call has been made by the researcher in order to explain the suitability of respondents. So, total 300 respondents were the target population. The geographical location of best 100 cooperatives in Malaysia is as in Table 1.

\section{Variable Measurement}

The questionnaire was designed in six sections: knowledge management, costing system, budgeting system, strategic analysis, information for decision making and performance measurement system. Each sub section included between four to seven questions as in table 2 .

Table 2. Measurement of variables

\begin{tabular}{|c|c|c|c|}
\hline Variables & No of Items & Source & Scale \\
\hline Knowledge Management & 7 & $\begin{array}{l}\text { Chan and Chao (2008), } \\
\text { Lee and Lan (2011) }\end{array}$ & $\begin{array}{l}\text { 1-Strongly Disagree, } \\
\text { 7- Strong Agree }\end{array}$ \\
\hline Costing system & 7 & \multirow{3}{*}{$\begin{array}{l}\text { Ittner, Larcker and } \\
\text { Rajan (1997) } \\
\text { Chenhall } \\
\text { Langfield-Smith (1998) } \\
\end{array}$} & \multirow{5}{*}{$\begin{array}{l}1 \text { - Lowest Extension } \\
\text { of Use, } \\
\text { 7- Highest Extension of } \\
\text { Use }\end{array}$} \\
\hline Budgeting system & 5 & & \\
\hline Strategic analysis & 4 & & \\
\hline Information for decision making & 5 & $\begin{array}{l}\text { Pavlatos and Paggios } \\
(2008)\end{array}$ & \\
\hline $\begin{array}{l}\text { Performance } \\
\text { system }\end{array}$ & 6 & $\begin{array}{l}\text { Chand and Ambardar } \\
(2013)\end{array}$ & \\
\hline
\end{tabular}

\section{Results}

\section{Descriptive Statistics}

In total, 123 questionnaires were returned out of 300 of questionnaires mailed out. 17 invalid replies were deleted and only 106 valid responses used for further analysis. Table 3 summarizes demographics most of the respondents that were sampled working as executive (40.6\%) and have 4 to 6 years working experience (36.8\%) at the respective co-operatives. As proven by the figures, respondents are qualified source of information for the study, with reliable working experience and exposed with contemporary MAP.

This study eliminated items with low reliability and validity prior conducting further analysis. Cronbach's $\alpha$ was used to measure the internal consistency of various constructs of the questionnaire (Nunnaly \& Bernstein, 1994). Cronbach's $\alpha$ for individual constructs is shown in table 4. All constructs were above 0.7 , which indicates that it has a satisfactory level of reliability (Hair, Black, \& Anderson, 2010). 
INTERNATIONAL JOURNAL OF ACADEMIC RESEARCH IN ACCOUNTING, FINANCE AND MANAGEMENT SCIENCES

Vol. 10 , No. 3, 2020, E-ISSN: 2225-8329 @ 2020 HRMARS

Table 3. Sample data and respondents' demographic

\begin{tabular}{|c|c|c|}
\hline & $\begin{array}{c}\text { Frequency } \\
(\mathrm{N}=106)\end{array}$ & Percentage \\
\hline \multicolumn{3}{|l|}{ Age } \\
\hline 20 to 30 years & 18 & 17 \\
\hline 31 to 40 years & 38 & 35.8 \\
\hline 41 to 50 years & 24 & 22.6 \\
\hline Above 50 years & 26 & 24.5 \\
\hline \multicolumn{3}{|l|}{ Academic Qualification } \\
\hline Malaysian Certificate of Education (Sijil & 14 & 13.2 \\
\hline \multicolumn{3}{|l|}{ Pelaiaran Malavsia) } \\
\hline Diploma & 21 & 19.8 \\
\hline Bachelors Degree & 43 & 40.6 \\
\hline Masters Degree & 23 & 21.7 \\
\hline Doctorates Degree & 5 & 4.7 \\
\hline \multicolumn{3}{|l|}{ Position } \\
\hline Chairman & 6 & 5.7 \\
\hline Secretary & 7 & 6.6 \\
\hline Bursary & 10 & 9.4 \\
\hline Boards Member & 8 & 7.5 \\
\hline Manager & 32 & 30.2 \\
\hline Executive & 43 & 40.6 \\
\hline \multicolumn{3}{|c|}{ Working experience with respective co-operatives } \\
\hline $1-3$ years & 19 & 17.9 \\
\hline $4-6$ years & 39 & 36.8 \\
\hline $7-9$ years & 16 & 15.1 \\
\hline $10-12$ years & 16 & 15.1 \\
\hline Above 12 years & 16 & 15.1 \\
\hline
\end{tabular}

Table 4. Measures of survey reliability

\begin{tabular}{lc}
\hline Variables & Cronbach's $\alpha$ \\
\hline Knowledge Management & 0.886 \\
Costing system & 0.768 \\
Budgeting system & 0.713 \\
Strategic analysis & 0.875 \\
Information for decision making & 0.693 \\
Performance measurement & 0.746 \\
CMAP & 0.876 \\
\hline
\end{tabular}

Table 5. Means for knowledge management

\begin{tabular}{ccc}
\hline & Means & Standard Deviation \\
\hline Knowledge Management & 5.1509 & 0.91862
\end{tabular}


Table 5 and 6 show the result of mean for knowledge management and contemporary MAP among the co-operatives in Malaysia. It is clearly shows that the level of adoption of knowledge management is high and the level of adoption of contemporary MAP also high. Generally it can be concluded that management accounting tools are needed in managing co-operatives regardless the revenue's size.

Table 6. Means for contemporary MAP

\begin{tabular}{lcc}
\hline & Means & Standard Deviation \\
\hline Costing system & 4.888 & 0.8514 \\
Budgeting system & 5.236 & 0.7663 \\
Strategic analysis & 5.142 & 1.1547 \\
Information for decision making & 5.283 & 0.8013 \\
Performance measurement & 5.401 & 0.6869 \\
\hline
\end{tabular}

\section{Analysis and Results}

Table 7 shows the correlations among knowledge management and contemporary management practices. It is clearly shows that organizational structure was associated with costing system $(r=0.503, p<0.01)$, budgeting system $(r=0.416, p<0.01)$, strategic analysis $(r=0.230, p<$ $0.05)$, information for decision making $(r=0.332, p<0.01)$, performance measurement system $(r=$ $0.360, p<0.01)$. Overall, organizational structure also has significant relationship with contemporary management accounting practices $(r=0.453, p<0.01)$.

Table 7. Result of hypothesis

\begin{tabular}{|c|c|c|}
\hline Hypothesis & R Square & Result \\
\hline $\begin{array}{l}\mathrm{H} 1 \text { There is a significant relationship between knowledge } \\
\text { management and costing system in the Malaysian Co- } \\
\text { operatives Sector }\end{array}$ & $.503^{* *}$ & $\begin{array}{l}\text { Significant } \\
(p<0.01) \\
\text { moderate }\end{array}$ \\
\hline $\begin{array}{l}\mathrm{H} 2 \text { There is a significant relationship between knowledge } \\
\text { management and budgeting system in the Malaysian Co- } \\
\text { operatives Sector }\end{array}$ & $.416 * *$ & $\begin{array}{l}\text { Significant } \\
(p<0.01) \\
\text { moderate }\end{array}$ \\
\hline $\begin{array}{l}\text { H3 There is a significant relationship between knowledge } \\
\text { management and strategic analysis in the Malaysian Co- } \\
\text { operatives Sector }\end{array}$ & $.230 *$ & $\begin{array}{l}\text { Significant } \\
(p<0.05) \\
\text { moderate }\end{array}$ \\
\hline $\begin{array}{l}\text { H4 There is a significant relationship between knowledge } \\
\text { management and information for decision making in the } \\
\text { Malaysian Co-operatives Sector }\end{array}$ & $.332 * *$ & $\begin{array}{l}\text { Significant } \\
(p<0.01) \\
\text { moderate }\end{array}$ \\
\hline $\begin{array}{l}\text { H5 There is a significant relationship between knowledge } \\
\text { management and performance measurement system in the } \\
\text { Malaysian Co-operatives Sector }\end{array}$ & $.360 * *$ & $\begin{array}{l}\text { Significant } \\
(p<0.01) \\
\text { moderate }\end{array}$ \\
\hline $\begin{array}{l}\text { H6 There is a significant relationship between knowledge } \\
\text { management and contemporary management accounting } \\
\text { practice in the Malaysian Co-operatives Sector }\end{array}$ & $.453^{* *}$ & $\begin{array}{l}\text { Significant } \\
(p<0.01) \\
\text { moderate }\end{array}$ \\
\hline
\end{tabular}

$* *$. Correlation is significant at the 0.01 level (2-tailed).

*. Correlation is significant at the 0.05 level (2-tailed). 
INTERNATIONAL JOURNAL OF ACADEMIC RESEARCH IN ACCOUNTING, FINANCE AND MANAGEMENT SCIENCES

Vol. 10 , No. 3, 2020, E-ISSN: 2225-8329 @ 2020 HRMARS

\section{Discussion and Recommendation for Future Research}

This paper has provided a potentially fruitful way of thinking about knowledge management and management accounting practices. Clarification on knowledge management embedded in organizational structure enhances our understanding the need to be dynamic in managing organization. The research findings contribute to previous literature that shows knowledge management is applied and considered as importance in managing organization (Gunasekera \& Chong, 2018; Stojanovic-Aleksic et al., 2019; Yao et al., 2020) . Our findings further emphasize the importance of costing system, budgeting system, strategic analysis, information for decision making and performance measurement system in sustaining organization Practically, results of this study has proven that knowledge management has significant effect on management accounting practices. In order to take advantage of knowledge management in organization, it is necessary to assume that the knowledge is not an exclusivity of each team. As a result of collaboration and exchange of knowledge, management team will be able to enjoy the contemporary management accounting practices. This will lead to the sustainability of organization especially with the global pandemic Covid 19 and economic disruption.

Even though statistical results have shown knowledge management has significant correlation with contemporary MAP, all hypothesis only correlate at moderate level. This could be due to the nature of cooperatives size of income. In average, revenue for the respondents about RM 250000 to RM300000. According to (Chen et al., 2010), knowledge management will be extensively use in the organization uphold innovativeness. The organization instill the courage of knowledge sharing among employees, create platform to facilitate knowledge exchange, promotes collaborative and facilitates knowledge discovery and creation.

Theoretically, knowledge management and management accounting practices are considered as strategic tools in managing organization. It is supported by Resource-Based View (RBV) Theory which highlights that each organization should exploit new opportunities using resources and competencies that are already available. In order to continuously sustain, resources should be valuable, rare, low imitability and organize to capture value (Barney et al., 2001). Therefore, cooperatives acknowledges that best practices of knowledge management and management accounting are intangible assets. These provide a more significant source of competitive advantage than tangible assets due to the barriers of replicating knowledge. This study has some limitations that can be further addressed in the future. Firstly, the mechanism of the influence of different level of factors such as individual, organizational and inter-organizational on the possible application of knowledge management practices. Secondly, the number of respondents can be increase since there are 14625 cooperatives registered in Malaysia.

\section{Acknowledgement}

This research has been carried out under University Research Grants (code: 2018-0115106-01 provided by Research Management and Innovation Centre (RMIC), Sultan Idris Education University (UPSI) 
INTERNATIONAL JOURNAL OF ACADEMIC RESEARCH IN ACCOUNTING, FINANCE AND

MANAGEMENT SCIENCES

Vol. 10 , No. 3, 2020, E-ISSN: $2225-8329$ @ 2020 HRMARS

\section{References}

Afrifa, G. A. (2016). Net working capital, cash flow and performance of UK SMEs. Review of Accounting and Finance, 15(1), 21-44. https://doi.org/10.1108/RAF-02-2015-0031

Ajmera, P. (2017). Ranking the strategies for Indian medical tourism sector through the integration of SWOT analysis and TOPSIS method. International Journal of Health Care Quality Assurance, 30(8), 668-679. https://doi.org/10.1108/IJHCQA-05-2016-0073

Alrawadieh, Z., Guttentag, D., Aydogan Cifci, M., \& Cetin, G. (2020). Budget and midrange hotel managers' perceptions of and responses to Airbnb: Evidence from Istanbul. International Journal of Contemporary Hospitality Management, 32(2), 588-604. https://doi.org/10.1108/IJCHM-012019-0015

Aris, N. A., Marzuki, M. M., Othman, R., Rahman, S. A., \& Ismail, N. H. (2018). Designing indicators for cooperative sustainability: The Malaysian perspective. Social Responsibility Journal, 14(1), 226248. https://doi.org/10.1108/SRJ-01-2017-0015

Barney, J., Wright, M., \& Ketchen, D. J. (2001). The resource-based view of the firm: Ten years after 1991. Journal of Management, 27(6), 625-641.

Bedford, D. S., Bisbe, J., \& Sweeney, B. (2019). Performance measurement systems as generators of cognitive conflict in ambidextrous firms. Accounting, Organizations and Society, 72, 21-37. https://doi.org/10.1016/j.aos.2018.05.010

Bulak, M. E., Turkyilmaz, A., Satir, M., Shoaib, M., \& Shahbaz, M. (2016). Measuring the performance efficiency of Turkish electrical machinery manufacturing SMEs with frontier method. Benchmarking, 23(7), 2004-2026. https://doi.org/10.1108/BIJ-09-2015-0089

Chan, I., \& Chao, C. K. (2008). Knowledge management in small and medium-sized enterprises. Communications of the ACM. https://doi.org/10.1145/1330311.1330328

Chand, M., \& Ambardar, A. (2013). Management Accounting Practices in Hospitality and Service Enterprises: A comparative research. Journal of Commerce \& Accounting Research, 2(3), 1-9.

Chen, C. J., Huang, J. W., \& Hsiao, Y. C. (2010). Knowledge management and innovativeness: The role of organizational climate and structure. International Journal of Manpower, 31(8), 848-870. https://doi.org/10.1108/01437721011088548

Cheng, M. M., \& Humphreys, K. A. (2016). Managing strategic uncertainty: The diversity and use of performance measures in the balanced scorecard. Managerial Auditing Journal, 31(4/5), 512534. https://doi.org/10.1108/02656710210415703

Chenhall, R. H., \& Langfield-Smith, K. (1998). Adoption and benefits of management accounting practice: An Australian study. Management Accounting Research, 9(1), 1-19. https://doi.org/10.1006/mare.1997.0060

Choong, K. K. (2018). Use of mathematical measurement in improving the accuracy (reliability) \& meaningfulness of performance measurement in businesses \& organizations. Measurement: Journal of the International Measurement Confederation, 129(February), 184-205. https://doi.org/10.1016/j.measurement.2018.04.008

Cooper, R. G. (2019). The drivers of success in new-product development. Industrial Marketing Management, 76(January 2018), 36-47. https://doi.org/10.1016/j.indmarman.2018.07.005

Dash, M. (2020). Applicability of the CVP Model for the Indian Sugar Sector. Asian Basic and Applied Research Journal, 2(1), 1-5.

De Zoysa, A., \& Herath, S. K. (2007). Standard costing in Japanese firms: Reexamination of its 
INTERNATIONAL JOURNAL OF ACADEMIC RESEARCH IN ACCOUNTING, FINANCE AND MANAGEMENT SCIENCES

Vol. 10 , No. 3, 2020, E-ISSN: 2225-8329 @ 2020 HRMARS

significance in the new manufacturing environment. Industrial Management and Data Systems, 107(2), 271-283. https://doi.org/10.1108/02635570710723840

Dewi, A., Ardina, C., \& Suardani, A. A. P. (2018). Cost-Volume-Profit (CVP) Analysis as a Profit Planning of Tour Packages at PT Tour East Indonesia, Denpasar. Journal of Applied Sciences in Accounting, Finance, and Tax, 1(1), 7-13.

Dogru, T., \& Sirakaya-Turk, E. (2018). Cash holdings and corporate governance: theory and contrary evidence from hotel firms. International Journal of Contemporary Hospitality Management, 30(10), 3117-3134. https://doi.org/10.1108/IJCHM-03-2017-0163

Alonso, D. A., \& Bressan, A. (2016). A resource-based view of the firm and micro and small Italian wine firms. International Journal of Wine Business Research, 28(4), 349-368. https://doi.org/10.1108/IJWBR-12-2015-0051

Ekemode, B. G., \& Olaleye, A. (2019). Asset allocation decision-making practices of institutional real estate funds in a developing economy: Evidence from Nigeria. Property Management. https://doi.org/10.1108/PM-03-2019-0012

Gebauer, H., \& Kowalkowski, C. (2012). Customer-focused and service-focused orientation in organizational structures. Journal of Business and Industrial Marketing, 27(7), 527-537. https://doi.org/10.1108/08858621211257293

Giovannoni, E., \& Quarchioni, S. (2019). Exploring the generative power of performance measurement systems design. British Accounting Review, 51(2), 211-225. https://doi.org/10.1016/j.bar.2018.11.002

Gonzalez, R. V. D., \& Melo, T. M. (2017). Linkage between dynamics capability and knowledge management factors: A structural equation model. Management Decision, 55(10), 2256-2276. https://doi.org/10.1108/MD-03-2017-0180

Greasley, A., \& Smith, C. M. (2017). Using activity-based costing and simulation to reduce cost at a police communications centre. Policing, 40(2), 426-441. https://doi.org/10.1108/PIJPSM-032016-0044

Guenther, T. W., \& Heinicke, A. (2019). Relationships among types of use, levels of sophistication, and organizational outcomes of performance measurement systems: The crucial role of design choices. Management Accounting Research, 42(May 2018), 1-25.

https://doi.org/10.1016/j.mar.2018.07.002

Guizani, A., Lakhal, F., \& Lakhal, N. (2018). The cash flow sensitivity of cash in family firms: does the board of directors matter? Managerial Finance, 44(11), 1364-1380. https://doi.org/10.1108/MF-10-2017-0440

Gunasekera, V. S., \& Chong, S. C. (2018). Knowledge management critical success factors and project management performance outcomes in major construction organisations in Sri Lanka: A case study. VINE Journal of Information and Knowledge Management Systems, 48(4), 537-558. https://doi.org/10.1108/VJIKMS-06-2018-0051

Hannila, H., Koskinen, J., Harkonen, J., \& Haapasalo, H. (2019). Product-level profitability: Current challenges and preconditions for data-driven, fact-based product portfolio management. Journal of Enterprise Information Management, 33(1), 214-237. https://doi.org/10.1108/JEIM05-2019-0127

Harris, D., \& Fitzgerald, L. (2017). Life-cycle cost analysis (LCCA): a comparison of commercial flooring. Facilities, 35(5-6), 303-318. https://doi.org/10.1108/F-10-2015-0071 
INTERNATIONAL JOURNAL OF ACADEMIC RESEARCH IN ACCOUNTING, FINANCE AND MANAGEMENT SCIENCES

Vol. 10 , No. 3, 2020, E-ISSN: $2225-8329$ @ 2020 HRMARS

Harun, H., Carter, D., Mollik, A. T., \& An, Y. (2020). Understanding the forces and critical features of a new reporting and budgeting system adoption by Indonesian local government. Journal of Accounting and Organizational Change, 16(1), 145-167. https://doi.org/10.1108/JAOC-102019-0105

Hvam, L., Hansen, C. L., Forza, C., Mortensen, N. H., \& Haug, A. (2020). The reduction of product and process complexity based on the quantification of product complexity costs. International Journal of Production Research, 58(2), 350-366.

https://doi.org/10.1080/00207543.2019.1587188

Ittner, C. D., Larcker, D. F., \& Rajan, M. V. (1997). The choice of performance measures in annual bonus contracts. Accounting Review, 72(2), 231-255. https://doi.org/10.2307/248554

Janudin, S. E., Halim, H. A., Habidin, N. F., \& Hanif, F. M. (2019). Contemporary management accounting practices and managerial performance amongst the Malaysian co-operatives sector. Research in World Economy, 10(5). https://doi.org/10.5430/rwe.v10n5p129

Kavitha, R. (2018). Cost Volume Profitability Analysis - An Empirical Study With Reference To Salem Steel Authority of India Limited (SAIL),Tamilnadu. International Journal of Business and Management Invention (IJBMI), 7(5), 46-51.

Choong, K. (2013). Understanding the features of performance measurement system: a literature review. Measuring Business Excellence, 17(4), 102-121. https://doi.org/10.1108/MBE-05-20120031

Kont, K. R. (2020). To buy or to borrow? Evaluating the cost of an eBook in TalTech library. Bottom Line, 33(1), 74-93. https://doi.org/10.1108/BL-07-2019-0100

Kristensen, T. B. (2020). Enabling use of standard variable costing in lean production. Production Planning and Control, O(0), 1-16. https://doi.org/10.1080/09537287.2020.1717662

Kuchta, D., Rynca, R., Skorupka, D., \& Duchaczek, A. (2019). The use of the multiple knapsack problem in strategic management of a private Polish university: Case study. International Journal of Educational Management, 33(2), 335-358. https://doi.org/10.1108/IJEM-03-2017-0068

Lee, M. R., \& Lan, Y. C. (2011). Toward a unified knowledge management model for SMEs. Expert Systems with Applications. https://doi.org/10.1016/j.eswa.2010.07.025

Maduro, S., Fernandes, P. O., \& Alves, A. (2018). Management design as a strategic lever to add value to corporate reputation competitiveness in higher education institutions. Competitiveness Review, 28(1), 75-97. https://doi.org/10.1108/CR-04-2017-0029

Malaysia Co-operative Societies Commission. (2011). National Co-operative Policy 2011-2020.

Maria Martinez-Leon, I., \& Martinez-Garcia, J. A. (2011). The influence of organizational structure on organizational learning. International Journal of Manpower, 32(5/6), 537-566. https://doi.org/10.1108/01437721111158198

McKinstry, S., Kininmonth, K., \& Mathieson, K. (2019). The introduction and operation of standard costing at J\&P Coats Ltd., 1925-1961: an institutional interpretation. Accounting History Review, 29(3), 369-389. https://doi.org/10.1080/21552851.2019.1660190

Nguyen, N. P., Evangelista, F., \& Kieu, T. A. (2019). The contingent roles of perceived budget fairness, budget goal commitment and vertical information sharing in driving work performance. Journal of Asian Business and Economic Studies, 26(1), 98-116. https://doi.org/10.1108/jabes-06-20180026

Nunnaly, J. C., \& Bernstein, I. H. (1994). Psychometric theory (Vol. 3). McGraw Hill. 
INTERNATIONAL JOURNAL OF ACADEMIC RESEARCH IN ACCOUNTING, FINANCE AND MANAGEMENT SCIENCES

Vol. 10 , No. 3, 2020, E-ISSN: 2225-8329 @ 2020 HRMARS

Oyadomari, J. C. T., Afonso, P. S. L. P., Dultra-de-Lima, R. G., Mendonça Neto, O. R. R., \& Righetti, M. C. G. (2018). Flexible budgeting influence on organizational inertia and flexibility. International Journal of Productivity and Performance Management, 67(9), 1640-1656. https://doi.org/10.1108/IJPPM-06-2017-0153

Pavlatos, O., \& Paggios, I. (2008). Management accounting practices in the Greek hospitality industry. Managerial Auditing Journal, 24(1), 81-98. https://doi.org/10.1108/02686900910919910

Rafi, M., Ahmad, K., \& Naeem, S. Bin. (2020). Budget harmonization and challenges : understanding the competence of professionals in the budget process for structural and policy reforms in public libraries. Performance Measurement and Metrics, 21(1), 1-15. https://doi.org/10.1108/PMM09-2019-0048

Ranajee, \& Pathak, R. (2019). Corporate cash holding during crisis and beyond: what matters the most. International Journal of Managerial Finance, 15(4), 492-510. https://doi.org/10.1108/IJMF-03-2018-0085

Reinking, J., Arnold, V., \& Sutton, S. G. (2020). Synthesizing enterprise data to strategically align performance: The intentionality of strategy surrogation. International Journal of Accounting Information Systems, 36, 100444. https://doi.org/10.1016/j.accinf.2019.100444

Sacks, A., Nisbet, A., Ross, J., \& Harinarain, N. (2012). Life cycle cost analysis: A case study of Lincoln on the Lake. Journal of Engineering, Design and Technology, 10(2), 228-254. https://doi.org/10.1108/17260531211241202

Kumaran, S. D., Ong, S. K., Tan, R. B. H., \& Nee, A. Y. C. (2001). Environmental life cycle cost analysis of products. Environmental Management and Health, 12(3), 260-276. https://doi.org/10.1108/09566160110392335

Kshirsagar, S., A., El-Gafy, M. A., \& Abdelhamid, S. T. (2010). Suitability of life cycle cost analysis (LCCA) as asset management tools for institutional buildings. Journal of Facilities Management, 8(3), 162-178. https://doi.org/10.1108/14725961011058811

Sharma, D., \& Sharma, U. (2020). Analysis of balanced scorecard usage by private companies. Pacific Accounting Review. https://doi.org/10.1108/PAR-06-2019-0076

Sitepu, E. M. P., Appuhami, R., \& Su, S. (2020). How does interactive use of budgets affect creativity? Pacific Accounting Review, 32(2), 197-215. https://doi.org/10.1108/PAR-05-2019-0054

Stojanovic-Aleksic, V., Eric Nielsen, J., \& Boskovic, A. (2019). Organizational prerequisites for knowledge creation and sharing: empirical evidence from Serbia. Journal of Knowledge Management, 23(8), 1543-1565. https://doi.org/10.1108/JKM-05-2018-0286

Susanty, A., Bakhtiar, A., Puspitasari, N. B., \& Mustika, D. (2018). Performance analysis and strategic planning of dairy supply chain in Indonesia: A comparative study. International Journal of Productivity and Performance Management, 67(9), 1435-1462. https://doi.org/10.1108/IJPPM10-2017-0250

Van VeenDirks, P. (2010). Different uses of performance measures: The evaluation versus reward of production managers. Accounting, Organizations and Society, 35, 141-164.

Vetchagool, W., Augustyn, M., \& Tayles, M. (2020). Impacts of Activity-Based Costing on Organizational Performance: Evidence from Thailand. Asian Review of Accounting. https://doi.org/10.1108/ARA-08-2018-0159

Willison, J., \& Buisman-Pijlman, F. (2016). Revising the budgeting model: challenges of implementation at a university. International Journal for Researcher Development, 7(1), 63-83. 
INTERNATIONAL JOURNAL OF ACADEMIC RESEARCH IN ACCOUNTING, FINANCE AND

MANAGEMENT SCIENCES

Vol. 10 , No. 3, 2020, E-ISSN: 2225-8329 @ 2020 HRMARS

https://doi.org/http://dx.doi.org/10.1108/MRR-09-2015-0216

Xiao, S., \& Oh, K. S. (2019). Unraveling the underlying mechanisms of new product development in high-technology emerging-market multinationals. Management Decision. https://doi.org/10.1108/MD-02-2019-0224

Yao, J., Crupi, A., Di Minin, A., \& Zhang, X. (2020). Knowledge sharing and technological innovation capabilities of Chinese software SMEs. Journal of Knowledge Management, November 2019. https://doi.org/10.1108/JKM-08-2019-0445 